\title{
Influenza surveillance in an urban area
}

\author{
W PAUL GLEZEN, MD
}

\begin{abstract}
WP GLEZEN. Influenza surveillance in an urban area. Can J Infect Dis 1993;4(5):272-274. In Houston the yearly influenza epidemics have been defined virologically by community surveillance obtained by testing specimens submitted from patients with acute respiratory illnesses seen by sentinel physicians. Mortality attributed to influenza and pneumonia has increased regularly during the period of intense influenza virus activity, but the peak has lagged two weeks behind the peak of activity defined by the virological surveillance. Most of the deaths occurred in persons aged 65 years and older; the average annual rate has been 103.5 per 100,000 in that age group. Hospitalizations for pneumonia and other acute respiratory conditions also peaked during influenza epidemics; the highest rate occurred in the elderly, but children under five years of age also had high rates. Morbidity in the ambulatory setting was highest in children. The average visit rate for children under five years of age was $28 \%$; the rate decreased to about $10 \%$ for persons aged 10 years and older. Improved coverage with more immunogenic vaccines is needed to protect the elderly. Young children would benefit from universal immunization with available live attenuated vaccines.
\end{abstract}

Key Words: Acute respiratory disease, Hospitalization, Influenza, Universal immunization

\section{Épidémiologie de l'influenza dans une zone urbaine}

RÉSUMÉ: À Houston, les épidémies annuelles ont bien été définies au plan virologique par les autorités sanitaires de surveillance épidémiologique grâce aux analyses de spécimens soumis par des patients atteints de maladie respiratoire aiguë vus par des médecins "sentinelles". La mortalité attribuée à l'influenza et à la pneumonie a augmenté régulièrement durant la période d'activité intense du virus de l'influenza, mais le pic du taux de mortalité a pris deux semaines de retard par rapport au pic d'activité défini par la surveillance épidémiologique du virus. La plupart des décès sont survenus chez des personnes de 65 ans et plus. Le taux annuel moyen a été de 103,5 par 100000 pour ce groupe d'âge. Les hospitalisations pour pneumonie et autres maladies respiratoires aiguës ont également atteint un pic durant l'épidémie d'influenza. Le taux le plus élevé est survenu chez les personnes âgées mais les enfants de moins de cinq ans ont également démontré des taux élevés. La morbidité dans le contexte ambulatoire a été la plus élevée chez les enfants. Le taux de visite moyen pour les enfants de moins de cinq ans a été de $28 \%$. Le taux a diminué à $10 \%$ pour les sujets de 10 ans et plus. Une protection améliorée, à l'aide de vaccins plus immunogènes, est nécessaire pour protéger les personnes âgées. Les jeunes enfants bénéficieraient d'une immunisation universelle à l'aide des vaccins vivants atténués disponibles.

Influenza Research Center, Department of Microbiology and Immunology, Baylor College of Medicine, Houston, Texas, USA

Correspondence and reprints: Dr W Paul Glezen, Department of Microbiology and Immunology, Baylor College of Medicine, One Baylor Plaza, Houston, TX 77030, USA. Telephone (713) 798-4469, Fax (713) 798-6802 
$\mathrm{T}$ He Influenza Research Center at Baylor College of Medicine, directed by Dr Robert B Couch, has performed epidemiological studies of influenza in Harris County, Texas for the past 18 years (1). Harris County, including the city of Houston, has a population that has increased from about two million to two-and-a-half million persons during that period. Epidemics have been defined by community surveillance of influenza virus infections detected by culturing samples from patients presenting to sentinel clinics with acute respiratory illnesses (ARI). Physicians in representative pediatric and family medicine clinics, serving both indigent and fee-for-service patients, were asked to culture from all patients presenting with ARI. A throat swab specimen was collected and placed in veal infusion broth with $0.5 \%$ bovine serum albumin. The specimen was kept at $4^{\circ} \mathrm{C}$ until delivered to the laboratory on wet ice. No loss of virus titre was noted for up to five days under these conditions. Each specimen was tested on a single Madin-Darby canine kidney (MDCK) tissue culture. The first hemadsorption was performed $72 \mathrm{~h}$ after inoculation. Hemadsorbing viruses were identified by enzyme immunoassay (EIA). Sample viruses were sent to the World Health Organization Collaborating Center at the Centers for Disease Control for further characterization.

An example of the community surveillance system is provided in Figure 1, which illustrates the number of patients cultured by week and the number positive for influenza viruses during the period from July 1985 through June 1990. Influenza B/Ann Arbor and A/Stockholm (H3N2) were the major viruses in the 1985-86 period and influenza A/Taiwan (H1N1) was the major virus for 1986-87. The major virus for 1987 -
88 was influenza A/Sichuan (H3N2); influenza B/Victoria and A/Taiwan (H1N1) were epidemic in 1988-89. A very intense epidemic caused by A/Shanghai/89 (H3N2) occurred in 1989-90. The epidemics were defined by the number of persons seeking care for ARI and the proportion positive for influenza viruses. Each winter the peak of ARI visits to the sentinel clinics coincided with the peak of the influenza epidemic defined by the positive cultures.

During the five-year period from 1985 to 1990, an average of 2254 persons were tested each year and almost $20 \%$ of these cultures from year-round surveillance yielded an influenza virus. The average isolation rate was $34 \%$ during the period of most intense influenza activity, which lasted for about 12 weeks per year. The length of the epidemic period ranged from 10 to 16 weeks; the longer epidemics usually involved activity of two distinct viruses.

During epidemics, a shift in the age distribution of persons with positive cultures has been consistently noted (2) . During the upward curve of the epidemic a large proportion of virus isolates was obtained from school children. As the epidemics progressed, an increasing proportion of infections was detected in adults and preschool children. This observation supports the concept that influenza spreads first through school children and then to their younger siblings and to adult contacts.

Observations in defined populations have allowed the determination of rates for medically attended illnesses and for acute respiratory disease (ARD) hospitalizations during the defined epidemic periods. Deaths of hospitalized ARD patients were counted and mortality rates calculated. Time series analysis showed that the peak occurrence of deaths lagged one week behind

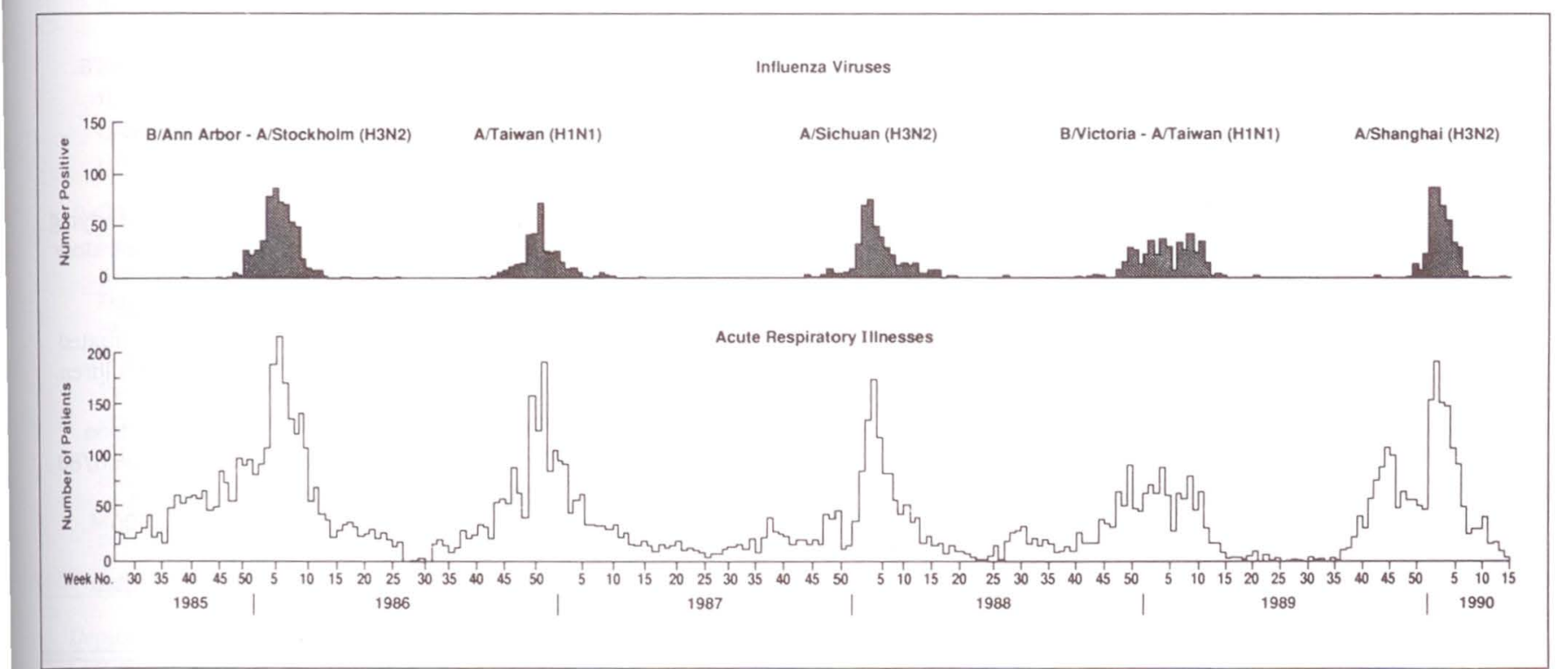

Figure 1) Number of persons presenting to sentinel clinics with acute respiratory illnesses, and number with positive cultures for influenza viruses, 1985-90 
TABLE 1

Age-specific rates for medically attended illness and mortality during influenza epidemics, Houston, Texas

\begin{tabular}{cccc}
\hline Age & Visits per 100 & $\begin{array}{c}\text { ARD } \\
\text { hospitalizations } \\
\text { per 100,000 }\end{array}$ & $\begin{array}{c}\text { P-I mortality } \\
\text { per 10,000 }\end{array}$ \\
\hline$<5$ & 28.0 & 42.7 & 2.7 \\
$5-9$ & 18.3 & 7.2 & 0.9 \\
$10-14$ & 9.9 & 3.5 & 0.9 \\
$15-19$ & 9.9 & 2.5 & 0.9 \\
$20-24$ & 9.1 & 5.2 & 1.1 \\
$25-34$ & 9.1 & 8.8 & 1.1 \\
$35-44$ & 11.7 & 11.6 & 1.1 \\
$45-54$ & 9.4 & 13.0 & 10.2 \\
$55-64$ & 10.2 & 20.7 & 10.2 \\
$\geq 65$ & - & 72.5 & 103.5 \\
\hline
\end{tabular}

ARD Acute respiratory disease; P-I Pneumonia-influenza

the peak of ARD hospitalizations which, in turn, lagged one week behind the peak of the epidemic defined by community surveillance $(3,4)$. The discharge records were also analyzed for underlying conditions that would classify the patients into categories at high risk of complications of influenza virus infections (5). Mortality rates were highest in the elderly patients 65 years of age and older who had at least one high risk condition; many had more than one listed on their discharge record (Table 1). The average mortality rate for persons 65 years of age and older was 103.5 per 100,000 during this period, but for the intense epidemic of the 1989-90 season, the rate rose to 210 per 100,000 .

The age-specific rates for ARD hospitalizations showed a different pattern. The rates were highest in persons aged 65 years and older, but the rates for children under five years of age were almost as high. Underlying conditions were not as prominent in the

ACKNOWLEDGEMENTS: These studies were supported by contract \#AI-15103 from the Respiratory Diseases Branch, DMID, National Institute for Allergy and Infectious Diseases, United States. The content of this publication does not necessarily reflect the views or policies of the United States Department of Health and Human Services, nor does mention of trade names, commercial products, or organizations imply endorsement by the United States Government.

\section{REFERENCES}

1. Couch RB, Kasel JA, Glezen WP, et al. Influenza: Its control in persons and populations. J Infect Dis $1986 ; 153: 431-40$.

2. Glezen WP. Serious morbidity and mortality associated with influenza epidemics. Epidemiol Rev 1982;4:25-44.

3. Perrotta DM, Decker M, Glezen WP. Acute respiratory disease hospitalizations as a measure of impact of discharge records of patients hospitalized with ARD; only $30 \%$ had underlying conditions that would put them in the high risk category. The hospitalization rates for elderly persons without chronic conditions were almost as high as for persons aged 65 years and older with chronic conditions, and were higher than the rates for high risk persons less than 65 years of age. Furthermore, only $13 \%$ of hospitalized children under five years of age had a high risk condition.

Using the number of women in the third trimester of pregnancy during the winter quarter as a denominator, it was found that Houston women in the third trimester of pregnancy have high risk of hospitalization with pneumonia during influenza epidemics. Their estimated rates were comparable with those of children under five years of age and were considerably higher than the rates for high risk persons in the 20- to 44-year age group.

The rates of visits for ARI were highest for children under 10 years of age. Above that age, the rates levelled off at approximately 9 to $12 \%$ during influenza epidemics.

Studies in Houston underscore the importance of influenza virus infections as causes of illnesses that may tax health care resources during the recurrent epidemics. Special attention should be directed toward the development of better methods of prevention for all high risk persons, especially persons 65 years of age and older. In addition to the currently recognized high risk groups, healthy young children and women in the third trimester of pregnancy are vulnerable to serious consequences of influenza. We recommend universal immunization of children under 10 years of age with attenuated, cold-adapted resortant vaccine (6-8), and immunization of women who will be in the third trimester of pregnancy during the influenza season with an inactivated subunit vaccine.

epidemic influenza. Am J Epidemiol 1985;122:468-76.

4. Glezen WP, Decker M, Joseph SW, Mercready RG Jr.

Acute respiratory disease associated with influenza epidemics in Houston, 1981-1983. J Infect Dis 1987;155:1119-26.

5. Glezen WP, Decker M, Perrotta DM. Survey of underlying conditions of persons hospitalized with acute respiratory disease during influenza epidemics in Houston, 1978-1981. Annu Rev Respir Dis 1987;136:550-5.

6. Gruber WC, Taber LH, Glezen WP, et al. Live attenuated and inactivated influenza vaccine in school-age children. Am J Dis Child 1990;144:595-600.

7. Clover RD, Crawford S, Glezen WP, et al. Comparison of heterotypic protection against influenza A/Taiwan/86 $(\mathrm{H} 1 \mathrm{~N} 1)$ by attenuated and inactivated vaccines to A/Chile/83-like viruses. J Infect Dis 1990;163:300-4.

8. Piedra PA, Glezen WP. Influenza in children: Epidemiology, immunity and vaccines. Semin Pediatr Infect Dis 1991;2:140-6. 


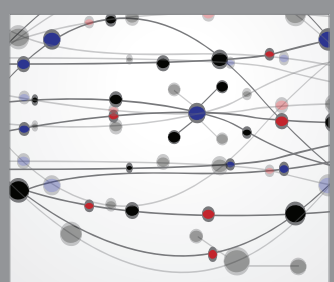

The Scientific World Journal
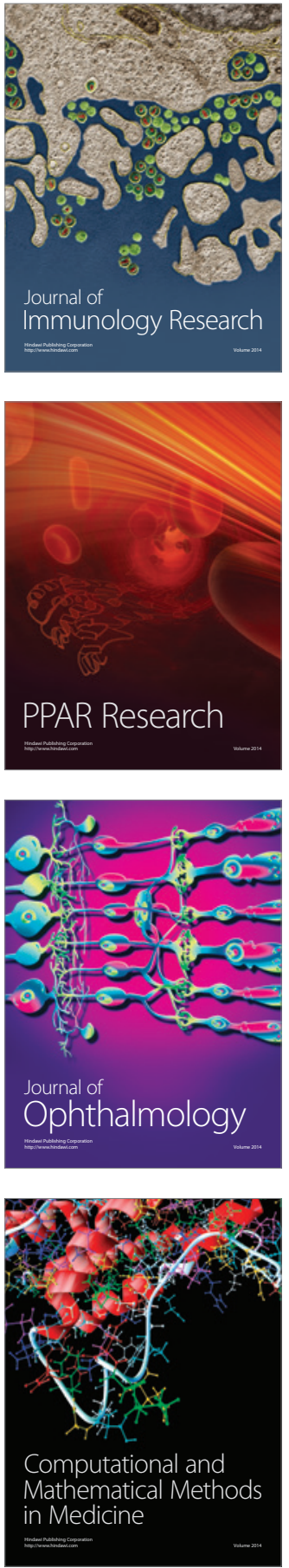

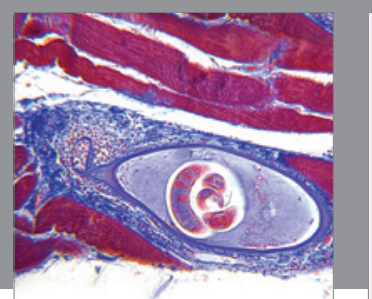

Gastroenterology Research and Practice

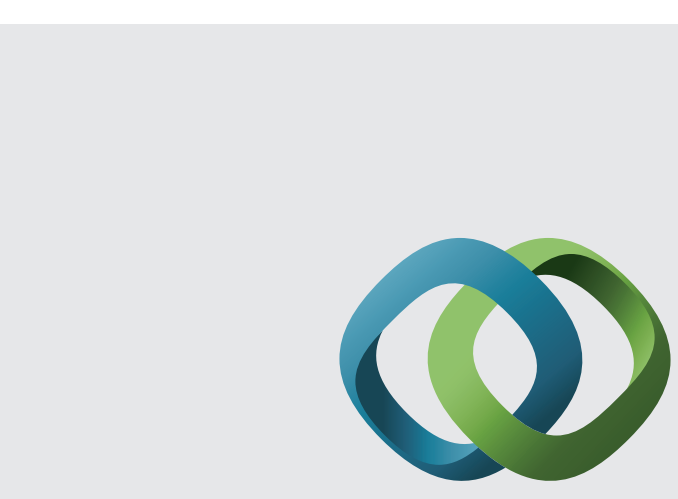

\section{Hindawi}

Submit your manuscripts at

http://www.hindawi.com
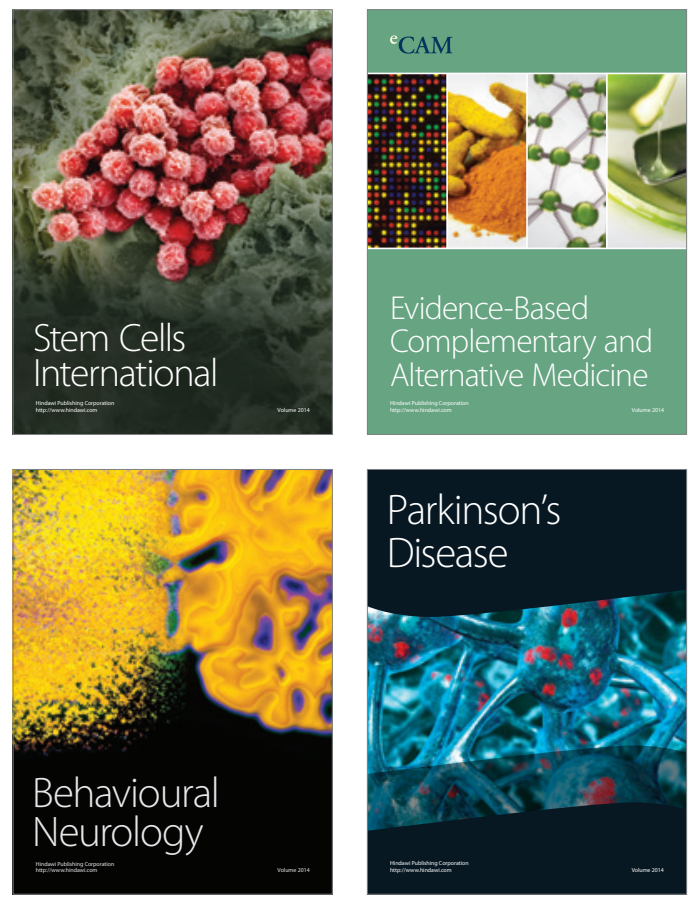
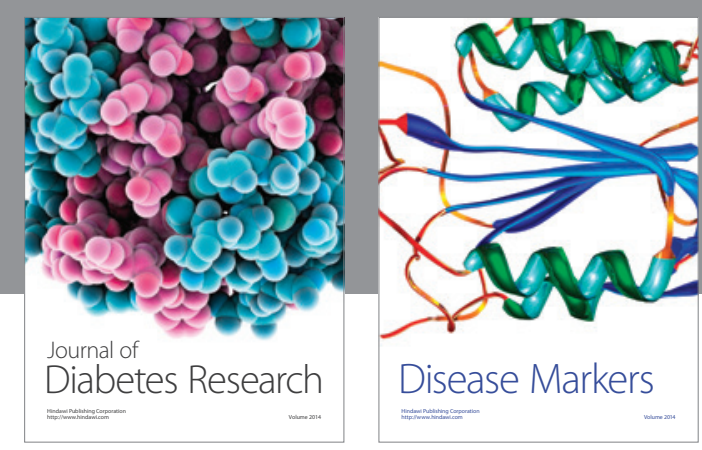

Disease Markers
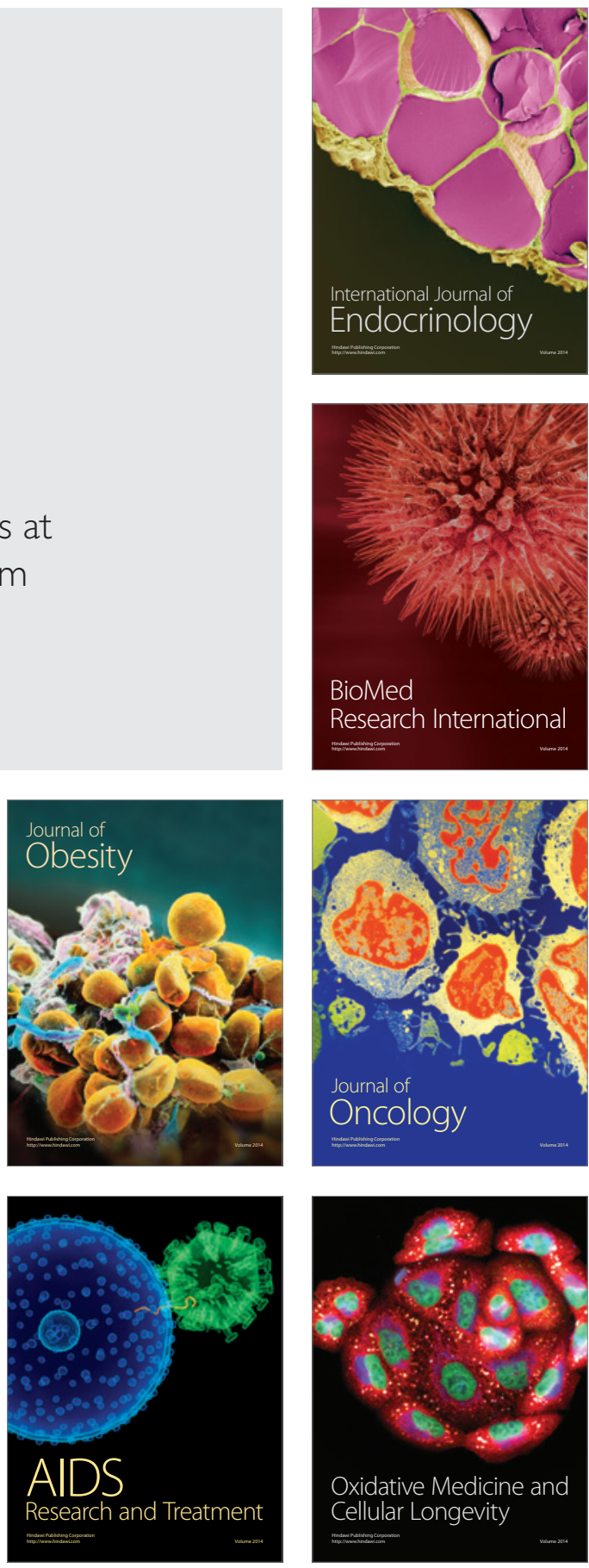